\title{
THE DETERMINANTS OF THE DOMESTIC RICE PRODUCTION FOR THE NEED OF THE POPULATION OF BENGKULU PROVINCE, INDONESIA
}

\author{
Efrita Edi", Kurniati Novitri, Feni Rita, Marwan Edy, Mufriantie Fithri \\ Faculty of Agriculture, Muhammadiyah University of Bengkulu, Indonesia \\ *E-mail: ediefrita@gmail.com
}

\begin{abstract}
The objective of this study is to analyze the determinants of the domestic rice production to meet the consumption needs of the population of Bengkulu Province of Indonesia. The data used are monthly time series data of the period from 2010 to 2015 . The analytical method used is multiple linear regression model. The results of the analysis show that the domestic rice production is affected by the rice area harvested, the rainfall, the rainy days, and the time which is a proxy of the technological change. The people and the government need to be on alert for the decline in the potential land for rice fields, the increased rainfall, and the decreasing rainy days that will affect the rice sufficiency in Bengkulu Province.
\end{abstract}

\section{KEY WORDS}

Production, consumption, rice, population, Indonesia.

Food is a basic human need that is the most fundamental and its fulfillment is a part of the human rights guaranteed in the Constitution of the Republic of Indonesia of the Year 1945 as a basic component for realizing quality human resources. Rice is the staple food of the greatest portion of the population of Indonesia. Other staple foods are maize, cassava and other tubers, sago, and wheat. Changing pattern of staple foods into rice and considering other foods inferior have caused rice to be the major staple food for most Indonesian people.

The status of rice as the main staple food makes it a national strategic commodity. The shortage of national rice stock and the rising of the rice prices can cause a disruption of economic stability and emergence of social and political turmoil. The national rice sufficiency to meet the current need of 258.7 million people must be recognized as a fundamental part of the food sovereignty and food self-sufficiency.

Food independence is measured with the ratio of the imports to domestic production (Suryana, 2008). The higher the imports, the more vulnerable the national food selfsufficiency. Therefore, the government should give the greater portion of attention to the domestic production rather than the imports.

The government continues reducing the imports and increasing the domestic rice production. These efforts have been successful in making Indonesia self-sufficient in rice in 2008 (Las, 2009). Furthermore, the government was trying to maintain Rice Self Sufficiency by issuing the Presidential Decree No. 5 of the Year 2011 that changed the rice surplus target of 5 million tonnes per year to 10 million tons per year. The government also issued Presidential Instruction No. 8 of 2011 in anticipation of production disruptions and rising prices of grain / rice caused by the extreme climatic conditions.

The problems encountered in meeting the need for rice from the domestic production are the high rate of population growth and percapita rice consumption which is higher than the national standard, so that the demand for rice is gradually becoming bigger and bigger. On the other hand, the acreage of the potential paddy fields is on the wane due to land conversion and the extreme climate which led to the reduced harvested area and the decrease of rice production. According to Irawan (2006) extreme climate causes the dry season to be longer resulting in drought and the rainy season to be longer causing flooding. Both drought and flooding adversely affect agricultural production, especially the short-lived crops like rice. 
Both of these phenomena can lead to the unstability of the rice availability and at a certain time a rice deficit will occur. According Sjarkowi and Noerdin (2015), to address the inadequacy of food (rice) due to the population growth (Malthusian trap) is to find a technological leap that can cause a rise in per capita consumption without the occurence of boomerang in the form of food shortages for the next generation. The staple food of the population of Bengkulu Province is rice. The acreage of the rice fields in the Province of Bengkulu is on the wane and the number of population in the period of the last forty years has increased more than threefold. Therefore, the writer is interested in doing an analysis of the determinants of the domestic rice production to fulfill the consumption needs of the population of Bengkulu Province.

\section{METHODS OF RESEARCH}

Time and Location of the Study. This study was conducted in the period from November through December 2016 in the Province of Bengkulu. The reason for choosing Bengkulu Province as the site of the study is due to the contribution of the sub-sector of agriculture to the GRDP is still fairly high at $31 \%$ and rice is the staple food of the population of Bengkulu Province. Additionally, in the Province of Bengkulu there is one city that always experiences a deficit in rice, which is surrounded by 9 regencies which are in surplus of rice.

Types and Sources of Data. The data used in this study are monthly time series data of the period of 2010-2015. The variables used are the number of population, per capita consumption of rice, domestic rice production, harvested area, rainfall and rainy days.

Analytical Model. The production and rice consumption needs are analyzed with the descriptive qualitative method presented in tabular form. The amount of rice production is obtained by converting the domestic rice production after being deducted by the portion used for feed and that which is scattered. The grain which is used for feed and that which is scattered is respectively 0.44 percent and 5.40 percent of the total rice production (Provincial Food Security Agency of Bengkulu, 2015). The dry milled grain conversion rate into rice is 62.74 percent (The Central Bureau of Statistics and the Ministry of Agriculture, 2015). Thus, the formula of the domestic rice production is:

It means that every 100 tons of grain production will generate as much as 59.08 tons of rice. Of that rice production, some is used for feed and some other is scattered, respectively 0.17 percent and 2.5 (Provincial Food Security Agency of Bengkulu, 2015). Thus, the formula of rice available for consumption of the population at the level of retailers and at the level of the households is as follows:

It means that every 100 tons of grain production will produce rice available for consumption of the population at the level of retailers and at the level of households as much as 57.50 tons.

The total consumption of rice of the population of Bengkulu Province is obtained by multiplying the per capita consumption of rice by its population. The data of rice consumption is obtained from PPH compiled by the Provincial Food Security Agency of Bengkulu.

To disclose the factors that affect the rice production, the multiple linear regression analysis is done. The general regression equation used is:

The dependent variable $(Y)$ which is incorporated into the model is the amount of rice (QPB) and the independent variables (X) are the rice harvested area (LP), acreage of crop failure $(P)$, rainfall $(C)$, rainy days $(H)$, and time $(T)$.

The method used is the Ordinary Least Squares method or OLS. The resulting equation must satisfy the classical assumption of normal distribution of data and free of autocorrelation, multicollinearity, and Heteroscedasticity (Greene, 1993).

To disclose whether or not the independent variables included in the model $\left(\mathrm{X}_{\mathrm{i}}\right)$ in the aggregate have effect on the amount of rice production $(Y)$ F-test was conducted. To disclose whether or not the independent variables included in the model $\left(X_{i}\right)$ partially affected the total amount of the rice production $(\mathrm{Y}) \mathrm{t}$-test was conducted.

To measure the magnitude of the diversity of the dependent variable $(Y)$ that can be explained by the independent variables $(X)$ which are incorporated into the model or the 
reliability of the model is calculated with the value of the coefficient of determination of Rsquare $\left(\mathrm{R}^{2}\right)$.

\section{RESULTS AND DISCUSSION}

Bengkulu Province consists of nine regencies and one municipality. The nine regencies are Bengkulu Selatan, Rejang Lebong, Bengkulu Utara, Kaur, Seluma, Mukomuko, Lebong, Kepahiang and Bengkulu Tengah. The City in Bengkulu Province which is also at the same time the provincial capital of Bengkulu Province. Of 1,992 hectares of area, there is only 92 thousand hectares of wetland (Central Bureau of Statistics of Bengkulu Province, 2016).

The agricultural sector plays a crucial role in the economy of Bengkulu Province. The role of the agricultural sector in the formation of the Gross Regional Domestic Product (GRDP) of the province reaches 30.66 percent. The agricultural sector provides employment and is the main livelihood of the population of Bengkulu Province where more than half (54.21 per cent) of the labor force employed in the agricultural sector (The Central Bureau of Statistics of Bengkulu Province, 2016). The agricultural sector is supported by its fertile soil and a climate that allows the cultivation to be done throughout the year. Based on the classification of climates of Schmidt and Ferguson, the type of climate of Bengkulu is classified into Type A.

The agricultural subsector of food crops has a dominant contribution compared to other agricultural subsectors. The largest food crop commodity is rice. The rice commodity consists of the wetland rice ( 93.46 percent) and the dryland rice (6.54 percent). After the rice, the second most commonly cultivated commodities are corn (The Central Bureau of Statistics of Bengkulu Province, 2016).

The rice production is intended to meet the needs of basic foodstuffs for the population of Bengkulu Province. The population of Bengkulu province is projected to increase from year to year. The results of the population census of Bengkulu Province in 2010 disclosed that the number of population of Bengkulu Province was 1,722,128 inhabitants. By 2015, the population of the Province of Bengkulu was projected to increase to 1,874,944 inhabitants (The Central Bureau of Statistics and the United Nations Population Fund, 2015).

The results of the calculation of the fulfillment of the consumption reveal that the availability of rice from the domestic rice production can meet the needs of the population of the Province of Bengkulu. This is consistent with the Map of Food Resilience and Food Vulnerability (Food Security Council, 2015) which states that Bengkulu Province is classified into the category of high surplus. These findings refute the statement Romdhon (2013) which states that Bengkulu Province experiences deficit in rice in which the domestic rice production meets only 30.39 percent of the needs of rice.

To disclose the factors that affect rice production in the Province of Bengkulu, the multiple linear regression analysis is performed. The dependent variable $(Y)$ which is incorporated into the model is the amount of rice production (QPB) and the independent variables $(X)$ are the rice harvested area (LP), the acreage of crop failure $(P)$, the rainfall $(C)$, the rainy days $(\mathrm{H})$, and the time $(\mathrm{t})$. The equation of the regression model used is: follows:

Based on the results of data processing by using SPSS, an equation is obtained as

It turns out that the regression obtained experiences a positive autocorrelation in which the value of Durbin-Watson (DW) is 1.436 below $\mathrm{dL}_{0.05 ; 5 ; 72}=1.4732$. According to Hidayat (2017) an autocorrelation causes the sample variance $\left(s^{2}\right)$ to be unable to describe the population variance $\left(\sigma^{2}\right)$, the resulting regression model cannot be used to estimate the value of the dependent variable of the value of particular independent variables, and the regression coefficient obtained is not accurate.

The autocorrelation problem is overcome by transforming the data with the method of Cochrane Orcutt. Based on the results of the regression analysis by using the data obtained from the Cochrane Orcutt transformation, it is disclosed that the value of DW is 1.845. The value of $\mathrm{dL}_{0.05 ; 5 ; 71}=1.4685$ and $\mathrm{dU}_{0.05 ; 5 ; 71}=1.7685$. The value of $\mathrm{DW}>\mathrm{dU} ; 1.845>1.7685$ and $(4-\mathrm{DW})>\mathrm{dU} ;(4-1.845)>1.7685$. The conclusion is that an autocorrelation does not 
occur. The regression model is also free of multicollinearity problems, where the value of tolerance is over 0.10 and VIF is less than 10. The resulting equation has been accurate, and it can be used for estimation. The equation after the transformation is as follows:

The reliability of the model or the coefficient of determination $\left(R^{2}\right)$ of the regression equation obtained is 0.971 . This means that 97.1 percent of the diversity of the dependent variable $(\mathrm{Y})$ can be explained by the variables of the rice harvested area (LP), the acreage of crop failure $(P)$, the rainfall $(C)$, the rainy days $(H)$, and the time $(t)$ which are incorporated into the model.

The $F$ test results show that the value of $F_{\text {count }}(438.75)$ is higher than the value of $F_{(0.01 \text {; }}$ $5 ; 65)(3,31)$. Thus, it can be concluded that variables of the rice harvested area $\left(L P_{t-1}\right)$, the acreage of crop failure $\left(P_{t-1}\right)$, the rainfall $\left(C_{t-1}\right)$, the rainy days $\left(H_{t-1}\right)$, and the time $\left(T_{t-1}\right)$ simultaneously significantly affect the amount of rice production $\left(\mathrm{QPB}_{\mathrm{t}-1}\right)$ at $\alpha 1$ percent. The influence of each of these variables is as follows:

1. The rice harvested area. The rice harvested area significantly affects the amount of rice production $\left(\mathrm{QPB}_{\mathrm{t}-1}\right)$ at a 1 percent. The regression coefficient of the rice harvested area $\left(\mathrm{LP}_{\mathrm{t}-1}\right)$ is 2.43. Based on this coefficient, it can be assumed that with the increase of 1 hectare of the harvested area, the rice production in the Bengkulu Province will increase by 2.43 tons.

The rice harvested area in 2011 decreased, then in 2012 and 2013 increased again, but in 2014 decreased again. In 2015, the rice harvested area decreased 12.70 percent compared to that of 2014 , in which the wetland rice harvested area decreased more than that of the dry land rice harvested area.

The decrease of the wetland rice harvested area is mainly due to the reduced potential of the wetland area. Although there have been attempts to create new wetland rice fields, but the shrinking of the wetland rice fields still continues occurring. The results of the study by Romdhon (2013), reveals that the shrinkage of the wetland rice fields in the period between 2006 and 2011 reached 13,199 hectares (10.87 percent) or 2,200 hectares per year (18.12 per cent per year). Based on the data from BPS (2013 - 2016), it is known that in 2012, a decrease in the wetland area can be reduced as much as 1,468 hectares. In 2013 the Regency of Bengkulu Utara succeeded in creating a thousand hectares of the wetland rice fields, so that the total area of the potential wetland rice fields in Bengkulu Province in 2013 increased by 352 hectares. However, in 2014 the acreage of the wetland rice fields decreased again by as much as 3,804 hectares (3.80 percent), and in 2015 the acreage of the wetland rice fields drastically decreased by as much as 4,599 hectares (4.78 percent).

The results of the observation on the decrease of the potensial wetland rice fields in the regencies / municipalities reveal that the largest decrease of the potential wetland rice fields occurred in the Regency of Seluma and Bengkulu Utara. But in relative terms, the decline of the wetland rice field area in the City of Bengkulu is larger than that of the regencies existing in Bengkulu Province, namely by 63.32 percent. This is especially caused by the insistence of the number of people who need the land for housing, roads, and offices.

According Romdhon (2013), the shrinking of the wetland rice field area in the Province of Bengkulu is caused by the conversion of the wetland rice fields into the plantations, especially oil palm plantations and into infrastructure, such as office buildings, housing, trade centers and so on, especially in the newly expanded areas.

The results of the study by Sugandi, et al. (2012), the conversion of the wetland into a palm oil plantation in Bengkulu Province is caused by non-economic and economic factors. Non-economic factors, such as the risk of the failure of the wetland rice farming which is fairly high, the lack of counselling intensity, the lack of knowledge of the rules of the conversion of the land use, and the constraints related to the unavailability of irrigation water. The economic factor is due to the value of the benefit (land rent) which is greater. If the wetland is planted with oil palm, the farmers' income will be higher by $8 \%$ than if it is planted with rice.

The conversion of the wetland function in Bengkulu Province also occurs in the transmigration areas. The results of the study by Hary (2012) show that the factors affecting the transmigrants to transfer their land function, among others are the number of productive 
family members; the duration of formal education; plantation crop seed aid from the government; and the membership of the farmer groups.

If the rice harvested area cannot be sustained and it continues declining, then certainly in the years to come, Bengkulu Province will be in a deficit of rice. The results of the study show that the regression coefficient of the rice harvested area (Lag_LP) is 2.433, and in 2015 , the rice harvested area is 128,833 hectares, the availability of rice from the domestic production is 332,718 tons, the number of population is $1,874,944$ inhabitants and the number of their rice consumption is 198,988 tonnes. The per capita rice consumption is $106.13 \mathrm{~kg}$ per capita per year, the population growth rate is 1.61 percent per year, and the level of rice production technology is assumed to be fixed and applicable in the subsequent years. If, in 2016 the wetland rice field area decreases just one percent less than that of the 2015 , the production of rice will be reduced by 2.433 multiplied by 1,288 hectares, or about 3,135 tons. And if the wetland rice field area continues decreasing at the same rate, then in 21 years to come, the availability of the rice from the domestic rice production will not be able to meet the needs of the rice of the population of Bengkulu.

If the rate of the decline of the harvested area is more than one percent per year, then the rice deficit will occur in a shorter period of time to come. If the rate of the decline in the wetland rice harvested area is 2 percent, then the rice deficit will occur in 15 years to come. And if the rate of the decline in rice harvested area in 2015 cannot be stopped and continues decreasing at the same rate, then the rice deficit will occur in 2019.

If, National Desirable Dietary Pattern in 2019 is in accordance with the main priority targets of the National Medium Term Development Plan (NMTDP) of 2015-2019, namely reaching the score of 92.5 where rice consumption has met the national standard of $91 \mathrm{~kg}$ per capita, then the results of the estimated deficit in rice in Bengkulu Province at the time of the decrease of the wetland area is respectively by 1 percent, 2 percent, and 12.7 percent, will respectively be 23, 20 and 6 years to come.

2. The Acreage of Crop Failure. The regression coefficient of the Acreage of Crop Failure (Lag_P) is 1.46, however, the variable of the Acreage of Crop Failure does not significantly affect the amount of rice production $(\mathrm{t}<\mathrm{t}(0.10 ; 65))$, so the Acreage of Crop Failure cannot be used to estimate the amount of rice production.

The Acreage of Crop Failure is the total area of the rice plants whose result is less than or equal to $11 \%$ of the normal condition. The crop failure can be caused by pests or diseases of the rice plants, flood, drought, or other causes such as landslides. The average area of crop failure at the time of the study was only 0.47 percent of the total harvest, with a range of 0.03 to 1.38 percent.

3. Rainfall. The pattern of planting or growing season is very much dependent on water availability, especially in the rainfed and the dry land rice fields. According to Surowinoto (1983) the rainfall needed by the rice plants is an average of $200 \mathrm{~mm}$ per month or more with the distribution for 4 months. The desired rainfall is around $1.500-2.000 \mathrm{~mm}$ per year.

The average rainfall per month in the Province of Bengkulu at the time of the study (2010 - 2015) was $262 \mathrm{~mm}$ per month with a range of $7-717 \mathrm{~mm}$. The average annual precipitation was $3,142 \mathrm{~mm}$ per year in the range of $2,500-3,981 \mathrm{~mm}$.

The trend of the rainfall per month that occurred in 2010-2015 was decreasing. The peak of the rainfall occurred around November and the lowest amount of the rainfall was around September.

The results of the study reveal that the regression coefficient of the rainfall (Lag_C) is 4.41. Based on this coefficient, it can be assumed or predicted that with the increased rainfall of $1 \mathrm{~mm}$, the production of rice in Bengkulu Provice will decrease as much as 4.41 tons. This is due to the high amount of rainfall in the Province of Bengkulu. Although it tends to decline, the average amount of the rainfall occurring each month is far above the average required by the rice plants to produce optimally.

The results of the study by Suriadi (2010) also show that the rainfall is one of the causes of the decline in rice production in West Java. The shifting of the rainy season for about a month can cause a decrease of rice production around 500,000 to 600,000 tons. 
According to McCarl et al. (2001) the impact of the climate change differs in each region. In one area the climate change can reduce production, but in other areas it can increase production. Saseendran et al. (2000) conducted a study on the effects of the climate change on the Humid Tropics in Kerala, India. The results of his study indicate that the increased rainfall causes rice production to increase exponentially. However, the decline in rainfall of 2-16 $\mathrm{mm} /$ day causes a constant decrease of production as much as 8 percent. Amin et al. (2015) conducted a study in Bangladesh on three types of rice plants (Aman, Aus and Boro). Aman rice plants are planted in the rainy season (June to August), Aus rice plants are planted in the dry season (March-April) and Boro rice plants are planted in the winter (December-January). The average annual rainfall in Bangladesh is $1,600 \mathrm{~mm}$. The results his study indicate that an increase in rainfall over the optimum requirement causes Aman rice production to decrease, but Aus rice production to increase.

According to Irawan (2006), the shifting of the rainy season is caused by the climate anomaly of El Nino and La Nina. The occurrence of El Nino is usually followed by a decrease in rainfall and an increase in air temperature. While the occurrence of La Nina stimulates the increase in rainfall above the normal level of rainfall. Both of these climate anomalies affect the agricultural production, especially in the short-lived crops. The crop failures at the time of El Nino are caused by the drastic decrease of the rainfall which causes a drought. At the time of La Nina, the rainfall increases dramatically, causing flooding. The climate anomalies of El Nino and La Nina are becoming more frequent with increasingly extreme seasonal condition and longer duration. The result is that the dry season is getting longer or the rainy season is getting longer, causing flooding.

The decrease in rice production is caused by harvesting failures or planting failures due to lack of or excessive rainfall. High rainfall in November and December leads to the fairly high possibility of flooding.

The farmers who are experienced will be planting in May-June so that the crop can be harvested in September-October. In November or December, they do tillage and plant, so that the peak of the harvest takes place in March-April. This is in accordance with the opinion of McCarl et al. (2001) who states that farmers can adapt to the climate change by changing the cropping season, replacing cultivar, changing irrigation practices, and change the allocation of land use.

4. Rainy Days. At the time of the study, it is revealed that the average number of rainy days in the period of 2010 - 2015 is 16 days per month. The number of rainy days per year ranges from 116 to 272 days. The highest number of rainy days is in December and the lowest is in August. In the period between June and October, the number of rainy days is s 14 days with a range of 11 to 14 days, and in the period from November to May, the number of rainy days $\geq 15$ days with a range of 15 to 23 days.

The number of rainy days per month from 2010 to 2015 tends to decrease. The lowest number of rainy days experiences a shift, whereas the highest number of rainy day remains in the period of November - January.

The results of the study reveal that the regression coefficient of the rainy days (Lag_C) is 110.70. Based on this coefficient, it can be assumed or predicted that with an increase of one rainy day, the production of rice in Bengkulu Province will increase by 110.70 tons. This may be due to the number of days of rain that occurred during the study tended to decrease. With increasing number of rainy days, the potential of production will increase, because the rainfall will be more evenly or in other words, the water remains available for rice cultivation.

Like a coin, a rainy day is on one side and a dry day on the other side. The dry days are calculated by reducing of the number of days in a given month by the number of rainy days (Suriadi, 2010). The decrease in the number of days of rain means the number of dry days increases and the potential for a drought also increases. The results of the study by Pramudia (2002), there is an inverse and exponential relationship between monthly rainfall and the progression opportunities of the dry days. The series of the dry days increase when the rainfall decreases. The opportunity of the dry day series of more than 15 days increases if the rainfall is below $20 \mathrm{~mm}$ per month. Many dry days occur during the dry season, within 
the period from June to September. The decrease of the rainy days in the dry season causes rice production to decline, so that a deficit in rice occurs in the dry season.

5. Time. Time is a proxy of the technology. Humans always make changes and adaptation of technologies so that the production of rice can fulfill their life needs. The results of the study reveal that the regression coefficient of time (Lag_t) is 68.18, which means that with an increase of time of 1 month, rice production increases by 68.18 tons.

Rice production can be increased through extensification and intensification efforts of rice plants. Extensification effort is difficult to carry out because the rate of creation of new wetland rice fields is slower than the rate of land conversion, so the potential of the wetland rice field area decreases each year. The decrease of the potential of the wetland rice field causes the potential of the rice harvested area to decrease.

The rice harvested area experiences a decreasing trend, although the steepness is not so apparent. Another effort that can be done is intensification or increased use of technology per unit area of land.

The results of the study by Hendri (2015) show that the area of the wetland rice fields, planted area, and seeds negatively affect production, whereas harvested area and the use of urea fertilizer have a positive effect. This study proves that the intensification efforts such as improved irrigation and technological innovation are more likely to increase rice production in the Province of Bengkulu than the extensification effort.

The successful implementation of these technologies can be measured by the productivity, namely the production per unit area of land. The rice productivity in this study is the rice production divided by the rice harvested area.

Rice productivity, both the wetland rice fields and the dry land rice fields in the Province of Bengkulu has an increasing trend over time. This finding is consistent with the results of the study by Simatupang and Maulana (2007), namely the trend that the rice harvested area tends to decrease but the productivity tends to increase.

According to Mohanty et al. (2012), this type of technology will allow farmers to adapt to the worsening of the global climate. The technology enables farmers to reduce the impact of climate change. To meet the rice sufficiency in the future, it is necessary to retain the potential of the wetland rice field which is still available, to increase cropping index, to mitigate climate change, and innovate the technology that can adapt to climate change.

\section{CONCLUSION}

1. Bengkulu Province is in surplus of rice, the domestic rice production can meet the needs of the rice consumption of its population.

2. The production of rice in Bengkulu Province is affected by the rice harvested area, the rainfall, the rainy days, and the time, which is a proxy of the technological change.

3 . The decrease in the potential of the wetland rice field that has an impact on the rice harvested area and an increase in rainfall should be looked out for in relation to the sufficiency of rice in the Province of Bengkulu.

The implication of these findings is that, if a decline in the harvested area of the wetland rice field occurs, it will lead to a deficit in rice. The higher the rate of the decline in the rice harvested area, the greater the opportunity for a rice deficit. The decline in per capita rice consumption will slow down the occurrence of the rice deficit. The step to be taken is to inhibit the rate of land conversion and to increase the cropping intensity and food diversification.

The highest number of rainfall occurs in the period of November - January and the lowest number of rainfall occurs in the dry season in the period of June-September. In these months the possibility of planting failure or harvest failure due to flood or drought is high. As a result, the likelihood of rice deficit in those months is also high. At that time the Government, which in this case is BULOG of the Regional Division of Bengkulu, must instantly take measures to prevent or to reduce the risk of rice deficit by distributing the stock of rice. 


\section{REFERENCES}

1. Anriany, D., and Martianto, D. 2013. Estimasi Sisa Nasi Konsumen di Beberapa Jenis Rumah Makan di Kota Bogor. Jurnal Gizi dan Pangan. 8(1):33-38.

2. BPS-Statistics of Bengkulu Province. 2016. Bengkulu Province in Figures. BPS-Statistics of Bengkulu Province. Bengkulu.

3. Cahyani, G. I. 2008. Analisis Faktor Sosial Ekonomi Keluarga Terhadap Keanekaragaman Konsumsi Pangan Berbasis Agribisnis Di Kabupaten Banyumas. Thesis. Program Magister Agribisnis. Program Pascasarjana Universitas Diponegoro Semarang. (Tidak dipublikasikan).

4. Chai, A. and Moneta, A. 2010. Retrospectives Engel curves. Journal of Economic Perspectives. 24(1): 225-240.

5. Efrita, E. 2001. Proyeksi Kebutuhan Beras dan Minyak Goreng di Provinsi Bengkulu dan Starategi Pengadaannya. Muhammadiyah University of Bengkulu.

6. Erwidodo and Pribadi, N. 2003. Permintaan dan produksi beras nasional: surplus atau defisit?. In Ekonomi Padi dan Beras Indonesia. Badan Penelitian dan Pengembangan Pertanian. Departemen Pertanian. Jakarta.

7. Food Security Agency of Bengkulu Province. 2015. Food Balance Sheet of Bengkulu Province 2015. Badan Ketahanan Pangan Provinsi Bengkulu. Bengkulu.

8. Food Security Agency of Bengkulu Province. 2016. Dietary Pattern of Bengkulu Province, 2015. Consuption and Food Security Division. Food Security Agency of Bengkulu Province. Bengkulu.

9. Food Security Council. 2015. A Food Security and Vulnerability Atlas of Indonesia. Dewan Ketahanan Pangan, Kementerian Pertanian and World Food Programme. Jakarta.

10. Hu, F. B. 2002. Dietary pattern analysis: a new direction in nutritional epidemiology. Current Opinion in Lipidology. 13(1):3-9

11. Lantarsih, R., Widodo, S., Darwanto, D. H., Lestari, S. B., dan Paramita, S. 2011. Sistem ketahanan pangan nasional: kontribusi ketersediaan dan konsumsi energi serta optimalisasi distribusi beras. Jurnal Analisis Kebijakan Pertanian. 9(1): 35-51.

12. Maxwell, D., Levin, C., Armar-Klemesu, M., Ruel, M., Morris, C., and Ahiadeke, C. 2000. Urban Livelihoods and Food and Nutrition Securuty in Greater Accra, Ghana. International Food Policy Research Institute in Collaboration withNoguchi Memorial Institute for Medical Research andWorld Health Organization. Research Report No. 112. Washington D. C

13. Nur, Y. H., Nuryati, Y., Resnia, R., and Santoso, A. S. 2012. Analisis Faktor dan Proyeksi Konsumsi Pangan Nasional: kasus pada komoditas beras, kedelai dan daging sapi. Litbang Perdagangan 6(1):31-52.

14. Park, S.Y., Murphy, S. P., Wilkens, L. R., Yamamoto, J.F., Sharma, S., Hankin, J.H., Henderson, B.E., and Kolonel, L.N. 2005. Dietary patterns using the food guide pyramid groups are associated with sociodemographic and lifestyle factors: the multiethnic cohort study. The Journal of Nutrition. 135:843-849.

15. Romdhon, M. 2013. Optimalisasi Lahan Sawah untuk Memenuhi Target Pendapatan Petani Setara Pendapatan Perkebunan di Provinsi Bengkulu: Pendekatan Stochastic Profit Frontier dan Goal Programming. Dissertation of Program Studi Doktor IImu-IImu Pertanian the Faculty of Agriculture, Sriwijaya University. Pelembang.

16. Sjarkowi, F. 2015. Kedaulatan Pangan, Siasat Agribisnis Pangan Kebangsaan Penguat Keutuhan NKRI. Badan Kajian dan Penerbitan ICMI Sumatera Selatan. Palembang. 